\title{
PENERAPAN METODE CERAMAH DAN DISKUSI SELAMA PEMBELAJARAN ONLINE
}

\author{
Retno Andini Pratiwi* \\ Email: retnoandini123@gmail.com \\ Program Studi Pendidikan Bahasa dan Sastra Indonesia \\ Fakultas Keguruan dan Ilmu Pendidikan \\ Universitas Riau
}

\section{Pengantar}

Pada masa pandemi yang melanda dunia mulai dari tahun 2019 membuat pembelajaran dilakukan secara online atau sekolah online. Pembelajaran dilakukan secara online merupakan salah satu upaya untuk memutus rantai penyebaran covid-19. Membahas mengenai pembelajaran tidak pernah luput dari namanya metode pembelajaran. Metode pembelajaran selama sekolah online tidak bisa dilakukan seperti pada sekolah biasanya. Hanya beberapa metode pembelajaran yang bisa diterapkan selama sekolah online, seperti metode ceramah dan diskusi. Metode tersebut dipilih karena terbatasnya ruang dan waktu bertatap muka. Mungkin semua orang bertanya-tanya tentang metode yang dipilih dalam pembahasan ini. Metode ceramah dan diskusi itu termasuk metode pembelajaran yang umum digunakan oleh seorang guru dalam proses pembelajaran. Oleh karena itu pada pembahasan ini membahas metode ceramah dan diskusi selama pembelajaran online agar kita semua mengetahui bahwa metode ceramah dan metode diskusi itu tepat atau tidak digunakan selama proses pembelajaran online.

\section{Pembelajaran Online}

Pembelajaran online merupakan proses pembelajaran yang sistem belajarnya dilakukan secara terbuka dan tersebar dengan menggunakan alat bantu yang membutuhkan jaringan internet atau teknologi yang berbasis jaringan agar dapat membantu proses belajar dan pemberian pengetahuan yang mengutamakan aksi dan interaksi antar guru dan siswa. Alat bantunya, seperti melalui aplikasi Zoom, Google Classroom, dan sebagainya (Novita Arnesi dan Abdul Hamid K, 2015). Pembelajaran online dilakukan dengan tidak bertatap muka langsung dan 
sangat berpengaruh terhadap kualitas jaringan. Keuntungan dari pembelajaran online berupa dapat menghemat waktu, tidak memerlukan ruang kelas, dan proses pembelajaran dapat terus berlangsung meski jarak guru dan siswa jauh. Sedangkan kerugiannya berupa para orang tua lebih ekstra mengawasi anak mereka, memerlukan android, terkendala oleh jaringan, dan lebih banyak mengeluarkan uang untuk membeli kuota internet.

Pembelajaran online menjadi pilihan kedua setelah pembelajaran ofline, seperti pada masa pandemi yang tidak memungkinkan guru dan siswa bertatap muka langsung untuk melakukan proses pembelajaran. Karena untuk meminimalisasikan penyebaran rantai covid-19. Hargreaves (2003) dan Jarvis (2007) menjelaskan bahwa pengetahuan dan wawasan yang dimiliki setelah melalui kegiatan pembelajaran menjadi penentu dan arah perilaku masa mendatang (Zulhafizh, 2020). Itu sebabnya, walaupun kondisi tidak memungkinkan, seorang siswa wajib melakukan pembelajaran agar mendapatkan pengetahuan.

Pembelajaran daring atau online pada masa pandemi (covid-19), diharapkan kualitas belajar siswa tidak menurun dan terus meningkat. Jika kualitas belajar dalam proses pembelajaran siswa menurun, maka memberikan dampak bagi mutu capaian belajar wawasan dan pengalamannya (Zulhafizh, Atmazaki, \& Syahrul, 2013). Karena itu peran guru sangat penting terutama dalam mengatur strategi pembelajaran. Meskipun proses pembelajarannya online, seorang guru tetap harus memperhatikan strategi pembelajaran yang diterapkannya. Salah satunya metode pembelajaran, seorang guru harus menentukan metode pembelajaran yang tepat digunakan selama pembelajaran online agar materi pembelajaran dapat diterima dengan baik oleh siswa. Karena jika seorang guru asal menggunakan metode pembelajaran, tentu saja proses pembelajarannya tidak terlaksana dengan optimal.

\section{Metode Pembelajaran}

Metode pembelajaran adalah cara yang digunakan oleh tenaga pendidik, seperti guru untuk menyampaikan materi pembelajaran agar dapat diterima dan 
dipahami oleh seorang siswa. Metode pembelajaran itu sangat penting dalam proses pembelajaran, dengan adanya metode pembelajaran seorang siswa dapat memahami materi pembelajaran dengan baik. Karena tidak semua materi pembelajaran dapat dipahami oleh siswa hanya dengan membaca buku di rumah. Terkadang orang menyepelekan profesi guru, namun profesi guru itu sangat besar pertanggungjawbannya karena seorang guru harus memilih metode pembelajaran yang tepat dalam setiap materi pembelajaran yang disampaikan, bukan asal menggunakan metode saja.

Prawiradilaga (2007), menyatakan bahwa metode pembelajaran adalah prosedur, urutan, langkah-langkah, dan cara yang digunakan guru dalam mencapai tujuan pembelajaran yang mana metode tersebut memfokuskan kepada pencapaian tujuan (Kusnadi, 2018). Maka tidak keliru jika metode pembelajaran sangat penting digunakan dalam proses pembelajaran agar dapat tercapainya tujuan pembelajaran yang sudah dirancang. Tentu saja yang menggunakannya adalah seorang guru ketika mengajar.

Proses pembelajaran itu diibaratkan sebagai dorongan atau kekuatan yang digunakan untuk meningkatkan dan mengangkut semua materi pembelajaran agar tepat sasaran, yaitu ke tujuan pembelajaran demi kepentingan peserta didik. Untuk mencapai itu semua seorang tenaga pendidik, seperti guru perlu mengaplikasikan beberapa cara, pendekatan, dan metode dalam proses pembelajaran tersebut agar pembelajaran itu dapat terlaksana secara efektif dan efisien. (Prayitno, 2009). Jika metode pembelajaran diterapkan hanya sendirian tidak diaplikasikan dengan pendekatan atau cara yang lain ada kemungkinan pembelajaran itu dapat terlaksana, namun tidak efektif dan tidak semua materi pembelajaran bisa ditangkap oleh seorang siswa. Karena itu diperlukannya pengaplikasian antara pendekatan dengan metode pembelajaran serta strategi pembelajaran yang lainnya.

Metode pembelajaran bukan hanya terdiri dari satu macam saja melainkan terdiri dari beberapa macam. Kusnadi (2018), menyatakan bahwa metode pembelajaran terdiri dari: metode umum dan metode khusus. Metode umum, seperti metode ceramah, metode tanya jawab, metode diskusi. Sedangkan metode 
khusus, seperti metode khusus pengajaran bahasa. Dari semua metode tersebut pembahasan kali ini hanya pemfokuskan pada metode pembelajaran yang umum digunakan oleh seoarang guru, yaitu metode ceramah dan metode diskusi. Karena metode ini yang bisa diterapkan pada pembelajaran online selama masa pandemi berlangsung.

\section{Metode Ceramah}

Metode ceramah salah satu metode yang sering digunakan oleh seorang guru. Metode ceramah adalah cara penyampaian materi pembelajaran dengan mengutamakan interaksi antara guru dan siswa. Dimana seorang guru menyamapaikan materi pembelajarannya melalui proses penerangan dan penuturan secara lisan kepada siswanya. Proses penyampaian tersebut bisa dibantu atau dilengkapi dengan menggunakan alat bantu, seperti gambar, video, dan lainnya (Raden Rizky Amaliah, Abdul Fadhil, dan sari Narulita, 2014). Pernyataan tersebut membuktikan bahwa seorang guru tidak hanya menerangkan dengan bercerita saja melainkan bisa dilengkapi oleh gambar ataupun video agar peserta didik tidak jenuh mendengarkan penjelasannya. Alat bantu yang digunakan saat menerangkan materi pembelajaran tidak hanya berfungsi menarik minat siswa melainkan juga meningkatkan konsentrasi seorang siswa sehingga siswa lebih paham dengan materi pembelajaran yang disampaikan.

Metode ceramah didalamnya sangat mengutamakan ucapan dari seorang guru. Oleh karena itu, seorang guru jika menggunakan metode ceramah dalam menyampaikan materi pembelajarannya harus menggunakan vokal atau ucapan yang jelas agar siswa mengerti dengan apa yang disampaikan dan kalimat yang diucapkan mudah dipahami oleh siswa serta apa yang disampaikan oleh guru tersebut jangan monoton sehingga metode ceramah termanfaatkan dengan baik. (Lufri, Ardi, dkk, 2020). Terkadang ada guru yang tidak mengerti dengan metode pembelajaran sehingga ketika menerangkan suara yang dikeluarkan sangat kecil dan tidak bisa didengar oleh semua siswa bahkan ada guru yang saat menerangkan temponya terlalu cepat dan juga membuat siswa tidak bisa memahami apa yang 
dijelaskannya. Karena itu seorang guru harus benar-benar memahami metode pembelajaran dan juga strategi pembelajaran yang lain dengan baik.

Keunggulan dari penggunaan metode ceramah salah satunya dapat menghemat waktu sehingga pada masa pandemi (pembelajaran online) seperti saat ini metode ceramah menjadi jalan utamanya dalam menyampaikan materi pembelajaran. Sebenarnya tidak hanya pada saat pandemi (pembelajaran online) saja, namun metode ceramah sudah selalu digunakan pada saat menyampaikan materi pembelajaran. Meskipun tidak bisa tatap muka secara langsung metode ceramah tetap bisa digunakan oleh guru untuk menyampaikan materi pembelajaran kepada siswanya selama pandemi (pembelajaran online) melalui aplikasi Zoom dan Google Meet. Pada Zoom dan Google Meet waktunya sangat singkat sehingga metode ceramah sangat tepat digunakan.

\section{Metode Diskusi}

Selain metode ceramah ada juga namanya metode diskusi. Metode diskusi adalah metode pembelajaran yang memfokuskan pada pertukaran pikiran antara guru dan semua siswa, pertukaran pikiran tersebut dilakukan untuk memecahkan persoalan atau sebuah masalah yang menyangkut materi pembelajaran yang diberikan guru kepada siswa atau bahkan persoalan yang diberikan siswa dan dipecahkan oleh siswa yang lain dan dibenarkan oleh seorang guru. Tentunya dalam metode ini semua siswa dapat berpendapat, menyangkal pendapat siswa yang lain, dan mengajukan saran maupun kritik (Ika Supriyati 2020). Sebelumnya guru memberikan topik atau materi pembelajaran yang dibahas dan disajikan baik dalam bentuk buku maupun Power Point. Gunanya agar pembicaraan dan pendapat siswa dalam memecahkan masalah tidak kemana-mana atau lari dari materi pembelajaran pada hari itu. Dalam artian harus adanya pembuakan dari guru sebelum memulai diskusi, baik itu aturan selama diskusi maupun pembagian materi atau topik agar metode diskusi dapat termanfaatkan dengan baik.

Metode diskusi sangat membantu siswa untuk melatih diri dalam berpikir logis, melatih diri untuk memutuskan suatu perkara, dan melatih diri agar lebih bisa menghargai pendapat orang lain. Melalui metode diskusi siswa juga bisa 
mendapatkan pengalaman baru, mendapatkan sebuah ide, dan bisa merasakan rasanya mempertahankan sebuah argumentasi (Habibati, 2017). Karena ada tipe siswa yang bisa memecahkan suatu persoalan dengan mendengarkan pendapat orang lain, dari pendapat orang lain siswa tersebut mendapatkan ide untuk memecahkan persoalan yang sedang dibahas. Melalui diskusi juga siswa akhirnya tau bagaimana menghargai pendapat orang lain dan menyanggahnya dengan bahasa yang tidak menyakiti orang tersebut.

Pada masa pandemi (pembelajaran online) metode diskusi sangat tepat digunakan apalagi kebanyak siswa yang terkendala dengan jaringan dan sangat menyulitkan guru untuk menerangkan materi pembelajaran melalui aplikasi Zoom dan lainnya. Sehingga alternatif yang digunakan adalah seorang guru menggunakan metode diskusi melalui aplikasi Google Classroom. Metode diskusi yang dilakukan guru pada aplikasi Google Classroom biasanya dimulai dengan seorang guru membagikan materi pembelajaran atau topik pada hari itu setelah itu diskusi dimulai dengan semua siswa dipersilakan bertanya, pertanyaan tersebut dijawab oleh semua siswa, dan jawaban yang diberikan boleh disanggah oleh semua siswa, serta akhirnya semua jawaban tersebut dibenarkan oleh guru. Dengan begitu pembelajaran dengan metode diskusi tepat diterapkan selama pandemi (pembelajaran online).

\section{Penutup}

Pembelajaran online merupakan pembelajaran yang mengutamakan jaringan dan dilaksanakan dengan cara tidak bertatap muka secara langsung. Karena itu pembelajaran online dilakukan selama masa pandemi agar terputusnya rantai penyebaran covid-19. Meskipun pembelajaran dilakukan secara online seorang guru tetap harus memperhatikan strategi pembelajaran, seperti metode pembelajaran. Semua metode pembelajaran itu dapat diterapkan dalam pembelajaran, tetapi tidak semua metode pembelajaran dapat diterapkan selama pembelajaran online. Pada pembelajaran online, metode ceramah dan metode diskusi sangat tepat digunakan. Karena dua metode pembelajaran tersebut mudah diterapkan dengan terbatasnya ruang dan waktu tatap muka, sehingga dengan 
menggunakan metode tersebut selama pembelajaran online dapat menyebabkan materi pembelajaran dapat terjangkau meski proses pembelajaran dilakuakan secara online, serta meskipun hanya dirumah para siswa tentunya mendapatkan wawasan dan pengetahuan yang didapat dari pembelajaran online.

\section{Referensi}

Amaliah, Raden Rizky, Abdul Fadhil, dan sari Narulita. 2014. "Penerapan Metode Ceramah dan Diskusi dalam Meningkatkan Hasil Belajar PAI Di SMA Negeri 44 Jakarta”. Jurnal Studi Al-Qur'an, volume (10), nomor (2). Arnesi, Novita dan Abdul Hamid K. 2015. "Penggunaan Media Pembelajaran Online - Offline dan Komunikasi Interpersonal Terhadap Hasil Belajar Bahasa Inggris”. Jurnal Teknologi Informasi \& Komunikasi dalam Pendidikan, volume (2), nomor (1).

Habibati. 2017. Strategi Belajar Mengajar. Banda Aceh: SYIAH KUALA UNIVERSITY PRESS.

Kusnadi. 2018. Metode Pembelajaran Kolaboratif: Penggunaan Tools SPSS dan Video Scribe. Jawa Barat: EDU PUBLISHER.

Lufri, Ardi, dkk. 2020. Metodologi Pembelajaran: Strategi, Pendekatan, Model,Metode Pembelajaran. Malang: CV IRDH.

Prayitno. 2009. Dasar Teori dan Praksis Pendidikan. Jakarta: Grasindo. Supriyati, Ika. 2020. "Penerapan Metode Diskusi dalam Pembelajaran Keterampilan Berbicara pada Siswa Kelas Viii MTSN 4 Palu”. Jurnal Bahasa dan Sastra, volume (5), nomor (1).

Zulhafizh, Atmazaki, \& Syahrul R. (2013). "Kontribusi Sikap dan Motivasi Belajar Siswa terhadap Hasil Belajar Bahasa Indonesia”. Jurnal Bahasa, Sastra dan Pembelajaran,

1(2), 13-28.

Zulhafizh. 2020. "Membina Aktifitas Belajar Mahasiswa di Perguruan tinggi Melalui Metode TIE (Translation, Interpretation, Extrapolation) pada Masa Pandemi Covid-19”. Jurnal kependidikan, 6 (3): 502-511. 


\section{*Data Penulis}

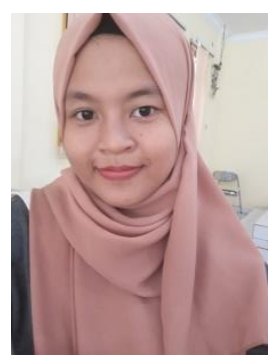

Retno Andini Pratiwi, lahir di Kampar, 30 September 2000. Pada tahun 2018, ia baru saja tamat dari SMA N 9 Pekanbaru dan pada tahun itu juga ia meneruskan studi pada strata satu Jurusan Pendidikan Bahasa dan Seni di Program Studi Pendidikan Bahasa dan Sastra Indonesia FKIP Universitas Riau melalui jalur SNMPTN (Seleksi Nasional Masuk Perguruan Tinggi Negeri). Saat ini ia tercatat sebagai mahasiswa strata satu Program Studi Pendidikan Bahasa dan sastra Indonesia di Universiatas Riau.

Prestasi yang didapat sebagai Finalis Duta Bahasa di Program Studi Pendidikan Bahasa dan Sastra Indonesia. Ia juga pernah mendapat amanah sebagai CO Perlengkapan pada acara Hijab Internasional 3 di SMA N 9 pekanbaru.

Buku: Tinta (Antologi Puisi), Semanggi (Antalogi Puisi Baru Stanza), Prasasti Usang (Antologi Cerpen), dan Panca Rona (Antologi Fabel). Buku tersebut termasuk karya semua mahasiswa Program Studi Pendidikan Bahasa dan Sastra Indonesia kelas 2018B dan ada yang termasuk karya gabungan antara mahasiswa kelas 2018B dengan 2018A.

Kontak:

Hp/WA : +6285274791294

Email : retnoandini123@gmail.com; retno.andini0768@student.unri.ac.id 